\title{
Deconstructing The Concept Of "AGIDI-IJESA" For National Integration: An Ethno-Linguistic Analysis Of Some Selected IJESA Proverbs
}

\author{
Olaosebikan T. O. Wende \\ Osun State University, College of Humanities and Culture, \\ Department of Languages and Linguistics, Ikire Campus, Osogbo, Nigeria.
}

\begin{abstract}
Nigeria parades about 250 distinct ethnic nationalities. The İjèsas, found in the SouthWestern geo-linguistic zone of the country are believed to be associated with "agídí" which, in the Yoruba world view, denotes stubbornness because of their tenacious stance on any course believed to be just, irrespective of the obstacles on their way. Many scholars have attempted to deconstruct the view with little or no success recorded. This paper, therefore seeks to deconstruct the erroneous pejorative impression that the concept has semantically attracted from the ethno-linguistic perspective with a view to creating a better understanding of the people's culture. Using the deconstructionist theoretical framework, twenty-one Ìjèsà proverbs were purposively selected for this analysis. The paper established that the concept represents enterprising, truthfulness, love, courage, hospitality, honesty, and sense of humour. Three historical facts, sourced from both classical and contemporary issues were cited to back up our claims. It concludes that the understanding of the cultural values of the federating ethnic groups is a panacea for national integration and development.
\end{abstract}

Keywords: Deconstructionist theory, agídí-Ìjèsà, İjèsà proverbs, ethno-linguistics, national integration.

\section{INTRODUCTION}

Yoruba language belongs to the Niger-Congo language family, which according to an Encyclopaedia Britannica's article is by far, the largest language family in Africa, indeed in the world, in terms of the number of languages spoken, their geographic extent and the number of speakers McGregor (2009: 314). Greenberg (2010: 1), who for the first time coined the term "Niger-Congo" to reflect the predominance of these languages in the great basins of the Niger and Congo rivers, estimates the number of Niger-Congo distinct languages to about 1,400 and affirms that each of them has separate dialects and additional variants. Akmajian (2009: 334) puts the total number of Yoruba speakers at 14 million, while Folorunso (2001: 5) identifies the states where Yoruba language is spoken to include: Oyo, Osun, Lagos, Ekiti, Ogun, Ondo, Kwara, Edo, Kogi and Delta States all in Nigeria. He further states that due to the historical circumstances surrounding the origin of the Yorubas, Yoruba speakers are not found in the same place again, some of them are found in the South-Eastern part of Benin Republic and some in the Northern part of Togo, especially in Atakpamé:

A l'heure actuelle, les Yoruba ne se trouvent plus dans le même endroit : au Sud-ouest du Nigéria, au Sud-est de la République du Bénin et à une partie du Nord du Togo surtout à Atakpamé

The Yoruba cultural empire equally extends to some parts of the Caribbean and American states like Cuba, Jamaica, Brazil and even Argentina. It has about 16 distinct dialects while 
Swahili, an East African language of about 32 million estimated speakers, has 17 and Igbo, an Eastern Nigerian language of 12 million estimated speakers, has about 11 distinct dialects Akmajian et al (2009: 334). These three languages belong to the same Niger-Congo language family. Ijesa dialect is one of the 16 dialects in Yoruba land which can be found in Nigeria. Other Yoruba dialects are: Òyó, Ègbá, İjèbú, Àwórì, Ègbádò, Ondo, Òwò, İkálè, Ìlàje, Ifè, Kétu, Sábe, İyàgbà, Àkókó, Èkìtì and İgbómìnà. Studies in dialectology have revealed that each of these dialects has additional variants due largely to economic and socio-political influences. African languages are in danger of extinction due to inadequate academic patronage and the overbearing influence of imposed foreign languages, especially English, French and Arabic on African indigenous languages in spite of the fact that these African indigenous languages are capable of expressing the great thoughts of the great minds of their great speakers in any field of human endeavour like their Western counterparts. This is probably why Gowon (2012: 8) calls for evolution of a national language:

...language remains the most important national symbol for any nation and serves as a propeller of national development "Nigeria has not evolved a truly national language to preserve its plans and strategy for national development... with over 250 languages and dialects in Nigeria, the best we can do is to record our achievement in English language..."

\section{What is a proverb?}

Proverb is a short well-known sentence or phrase that states a general truth about life or gives advice. In the view of Ssetuba (2005: 61), proverb is regarded as "A noble genre of African oral tradition that enjoys the prestige of a custodian of a people's wisdom and philosophy of life" Ssetuba's definition situates proverb among the African oral traditional genres, it also pinpoints the conservational role it plays in people's cultural values. Delano (1983: VI) defines proverb as "the horse of words: if a word is lost, proverb is used to find it." Delano's definition is literally translated into French by Ahmadou Kourouma (1998: 42) when he says: "Le proverb est le cheval de la parole: quand la parole se perd, c'est grâce au proverbe qu'on la retrouve." This definition is extremely metaphorical and philosophical to concretely explain what proverb means, it however enjoys some degree of prestigious acceptability.

Achebe (1958: 5) refers to proverb metaphorically as "the palm oil with which words are eaten." The definition is also guilty of being extremely philosophical for easy comprehension. Looking at proverb from the functional and content perspectives, Akakuru, (2008: 61), conceives proverb as a short saying or sentence, generally known by many people and which usually contains words of wisdom, truth or morals that are based on common sense or practical experience...a description of a basic rule of conduct that all people generally follow or should follow" This definition is comprehensive in presenting proverb as a typified people's unwritten constitution that guides their attitudes and relationship with others.

\section{The Ijesas: dialect and proverbs}

"Agidi," in the Yoruba world view denotes stubbornness, recalcitrance, unrepentance and being heady. Due to over-generalisation and misconception of the concept, the Ijesas, of all other Yoruba ethnic groups, are believed to be stubborn because of their uncompromising stance on any course they believe to be just, irrespective of the obstacles on their way. Like other Yoruba kingdoms, history has it that the Ijesas migrated from Ile-Ife to settle in Ilesa. The founder of the kingdom, Ajíbógun is the youngest son of Olófin (Odùduwà), the progenitor of the Yorùbá race. Although, another version of the oral tradition explains that Olófin has only one child, Òkànbí, who in turn has seven children. At a point in history, Olófin was suffering from an old age sight impairment. Out of all his children or grand-children, only Ajíbógun voluntarily 
agreed to go and fetch the ocean water (omi òkun) and he successfully went and came back with the water which was used to cure Olofin's blindness.

Armed with idà-Àjàsé (sword of conquest), the only thing which Ajíbógun inherited from his father Odùduwà, he moved from Ilé-Ifè towards the upper reaches of Òsun, Sásá and Òni rivers which flow south and southwest into the Lagos lagoon and founded the İjèsà kingdom. The great exploit earned him the appellation of "Obokun" meaning "the one who fetches the ocean water" which later became the royal title of Ajíbógun when he finally settled and founded İjèsà Kingdom. That also must have informed the love, the determination and the zeal which the Ijesas have for adventure. In fact, Lamikanra cited by Oyeweso (2011: xii) while describing the spread of Ijesa influence across the length and breadth of Nigeria writes: "There is no town of note, and there is hardly any village of any consequence in Nigeria, without a colony of Ijesa. We are an adventurous race who has no fear of distance and strange customs; we have exploited these characteristics to spread our influence far and wide" The economic quest of the early Ijesa merchants earned them the popular appellation "Òsómàáló"

The Ijesas are also fearless fighters for justice and equity. This accounts for Ògèdèngbe's collaboration with Fábùnmi of Òkè-Ìmèsí to successfully resist the Ibadan imperialism by leading the Èkìtìparapò confederacy which fought the Ibadan army under Ààre Látòòsà to a standstill between 1877 and 1893. In the present Ijesa Kingdom, there are six local government areas consisting of: Ilesa East with the Headquarters at Iyemogun, Ilesa West with its Headquarters at Òkè-Omiiru, Àtàkúmòsà East which has its Headquarters at Ìperindó Ògèrè-Ekùn, Àtàkúmòsà West with its Headquarters at Òsú. Others are Obòkun and Oríadé with their Headquarters at Ìbòkun and Ìjèbú-Jèsà respectively. Apart from Ilesa, other notable towns and villages in Ijesaland are: Èsà-Òkè, Èsà-Odò, Ìmèsí-Ilé, Òtan-Ilé, Ìlàrè, Àjìdò-İjèsà, EtíÒni, Ìpetu-İjèsà, Òwenà-Ìjèsà, Ìkeji-Arákeji, Ėrìn-Òkè, Èrìnmò- İjèsà, Kájolà, Ìtagúnmodi, İjèdá, Ìlokò, Ifèwàrà, İpòndá and a host of others.

Oyeweso (2011: $\mathrm{x}$ ) describes the Ijesas in the following words:

Ijesas are one of the most interesting people in the world. They are industrious, enterprising, gregarious, disciplined, fiercely loyal, stickler for integrity and never forget their benefactors...

In this citation, Oyeweso makes an intelligent reference to the three and half years legal battle which an İjesà waged against an incumbent governor in Osun State from 2007 to November 2010. Arégbésolá believed that he won the 2007 governorship election, the courage and the zeal with which he pursued the case up to the court of appeal where the then incumbent Governor was unseated is the attestation to the facts that the Ijesas are dogged fighters for justice.

Ethno-linguistics or cultural linguistics is a field of Linguistics which studies the relationship between language and culture, and the way different ethnic groups perceive the world. It is the combination between Ethnology and Linguistics. The former refers to the way of life of an entire community, that is, all the characteristics which distinguish one community from the other. Those characteristics make the cultural aspect of a society. Ethno-linguists studies people's culture with reference to their linguistic endowment. This definition is undisputable since language is an indispensable aspect of people's culture. In fact, "It is language, more obviously than anything else that distinguishes man from the rest of their animal world." Barber (1964) cited by Babatunde (1997: 3). Haugen (1974) complements the observation about the unique nature of human language when he describes language as "Man's most distinctive and significant type of social behaviour... learned anew by every child." 
An ethno-linguist therefore shows the way perception and conceptualization influence language and how this is linked to different cultures and societies. In the light of the above, we shall tailor our discourse towards deconstructing the concept of "agídí-İjèsà" as it is perceived among the other tribes in Nigeria and in the world. We shall then use some selected Ijesa proverbs to explicate what the concept actually stands for.

\section{Deconstructionist theory}

Deconstructionism is a critical dismantling of tradition and traditional modes of thought. It is a form of philosophical and literary analysis, derived mainly from the work begun in the 1960s by the French philosopher Jacques Derrida, that questions the fundamental conceptual distinctions, or "oppositions," in Western philosophy through a close examination of the language and logic of philosophical and literary texts. In the 1970s, the term was applied by Derrida to the works of Paul de Man, J. Hillis Miller, and Barbara Johnson, among other scholars. In the 1980s, it designated more loosely a range of radical theoretical enterprises in diverse areas of the humanities and social sciences, including law, psychoanalysis, architecture, anthropology, theology, feminism, gay and lesbian studies, political theory, historiography, and film theory. In polemical discussions about intellectual trends of the late 20th-century, deconstruction was sometimes used pejoratively to suggest nihilism and frivolous scepticism. In this paper, we try to deconstruct a misconstrued concept about the İjèsàs using 20 proverbs in the dialect of the people. The number is reliable because it cuts across 8 attitudinal representations of the people.

\section{DISCUSSION AND ANALYSIS}

The term "agídí-Ijèsà" is synonymous with some general qualities encapsulated in the available samples of this research which reveal that the concept actually stands for: hospitality, generosity, enterprising, courage, fearlessness and bravery, hard-work, truthfulness and faithfulness, integrity and self-esteem, respect for elders and constituted authority, sense of humour, rational and logical thinking. The awareness of these qualities is fundamental to achieve national integration.

\section{Hospitality and Generosity}

\section{É sún un an f'ògèdè é se l'álè İjèsà, eye léé jé}

(Plantain to an İjèsàman is food only for the birds)

Literally, it means that in Ijesaland, plantain is produced abundantly to the extent that many of them get ripe on their trees and are consequently eaten by birds. The forest nature of Ijjèsà makes agriculture a profitable and major occupation of the people. Crops produced by them include yam, cassava, plantain, maize, rice and cash crops like cocoa, kola nut and coffee. The people are known for being passionately hospitable and generous, take good care of their guests, especially foreigners. This means that an İjèsà is ready to give part of his possession to take care of his guest. The attribute gave birth to the popular proverbial expression above in which two lexical items are symbolic. "Ògèdè" and "eye" which respectively symbolize possessions and foreigners. As it is difficult to identify birds in the air, so also it is difficult to identify foreigners for selective treatment. This reinforces the religious belief of the people in Olódùmarè (God) as the Chief-Provider.

\section{Èló a mú komodé ká a síó ojú oni íwò?}

(Give the child a little and stop him from looking covetously)

Denotatively, this is a rhetorical proverbial expression asking how much will be given to an infant to stop him from looking at one's face covetously? In child psychology, between age 5- 
12, children are naturally possessive and self-centred. Their digestive enzymes are hypersensitive and this explains why they tend to consume more than the adult. Consequently, children want to get what the adults around them eat and any attempt to deny them may lead to frustration or maladjustment. They look at such adult with little or no respect. The İjèsàs are conscious of this and in their attempt to prevent such unpleasant situation; they readily give part of what belongs to them to the children around them. At the connotative level, it shows that the Ijesas can sacrifice their comfort, belongings and time in order to make others happy. It is an expression of altruism in a way.

\section{K'éúré bá d'Ájìdò á k'oìpo}

(Take a goat to Àjìdò, it will refuse to eat tuber's bark)

If a goat gets to Àjìdò, it will reject tuber's bark. Naturally, goats are fed with tuber's bark but because the Àjìdò indigenes, in their quest to show hospitality even to an animal, will feed new goats with other food items richer in quality and in quantity than the tuber's bark. The import of the proverb lies in its symbolic representation of the two lexical items eúré (goat) and eìpo (tuber's bark). Goat symbolizes an ungrateful foreigner while tuber's bark stands for care morally or materially. Àjìdò is a village in the present Àtàkúmòsà East Local Government. The ethnocentrism, generosity and hospitality of the natives are always taken for granted by some unscrupulous non-natives after staying there for a long period. In extreme cases, some use to attempt to snatch the wives or the land belonging to their landlords no sooner than they establish themselves.

\section{Enterprising and Industrious \\ Oní tajà erùkù, á gboó òkúta}

(He who sells dust shall be paid pebbles)

He who sells dust shall be paid with pebbles. The Ijesas are reputable in trading and industrialization to the extent that they are up till today referred to as "Òsómàáló" a nick-name which means making one's debtor to feel uncomfortable by squatting down and refusing to leave the premises of the latter until he/she redeems his/her indebtedness. They are successful ubiquitous traders. According to Oyeweso (2011: xii):

The study of the history of the İjèsàs shows that the people have impressive political, social and economic systems in the pre-colonial period. In the economic sphere, they are noted for their business and entrepreneurial skills as exemplified in the Òsómàáló phenomenon. The Òsómàáló were the itinerant İjèsà traders who extended the frontier of İjèsà business outside İjèsàland in such places like Ìbàdàn, Ògbómòsó, Ìkàré, Bída, Gbókò, Mokwa, Oturkpo...

Many of them are also established business owners in Abidjan, Porto-Novo, Lome, Ghana, Brazil and Cuba. Proverb 4 above succinctly captures their attributes of being enterprising and industrious. Ojà erùkù denotatively means dust but connotatively means fake product. oó òkúta denotatively means pebbles but connotatively, it means regret. Deeply, the proverb shows that the İjèsàs place premium on their integrity and the standard of their goods and services in the course of their commercial activities.

\section{Òdájú ló bí oó, ùtìjú ló bí gbèsè}

(Audacity brings money, timidity bankruptcy)

One may be tempted to ask why a trader needs to squat (lósòó) while requesting his debtors for payment. Proverb 5 above provides an answer to the puzzle, it attributes success in 
business to audacity and bankruptcy to mildness or timidity. Since business succeeds when friends and relatives pay for their goods and services, a successful İjèsà trader is typically audacious. Whenever they sell on credit, they employ different methods including but not limited to threat, persuasion, begging and reporting. But when all of these instruments of debt retrieval are exhaustively explored without any dint of success, embarrassment and incapacitation become the last resort by a typical İjèsà trader. He or she will visit the debtor at odd hours either early in the morning to incapacitate him from going out for the day's job or late in the evening to prevent him from the usual evening relaxation. In each situation, the trader usually squats on the bear floor to embarrass the creditor. If a passer-by asks why the trader takes such position, the response is always that he will not leave the premises of the debtor and that he will remain squatting until the creditor repays his debt. The deep meaning of the proverb is that fortune always smiles at the audacious.

\section{Elú i dájà kómo alálè mó na}

(Market-god will not create a market forbidden for its children)

Elú -the god of market- does not found a market which his children will not patronize. This proverb points to the fact that the people under review are simply businesslike; it underscores the ubiquity of Ijjèsà traders. They always endured the stress and the risk associated with offshore trading by walking long distances for several days, weeks and months in the valleys, creeks, mountains, forests and deserts, villages, cities and towns in pursuant of their commercial activities when transport system was still by foot. Now that transportation has improved, the people are contributing maximally to the economic advancement of their communities.

\section{Hard work and integrity}

\section{Olókùnrùn ó pé lúlé ayé àpénù ló pé}

(Longevity of life of a sickler is liability to humanity)

Culturally, the İjèsàs are very hardworking in order to preserve their integrity and honour. Up till today, hardly can one see an İjèsà man begging for alms in the street as it is common among other tribes. They believe that a responsible man must work to be able to play his role as the head of the family. They hate laziness with passion, hence the encapsulation of this hatred in the above proverb. Denotatively, olókùnrùn is a sickler, by nature he is incapable to add values to his family or society. Deeply, ókùnrùn is the extreme end of laziness, no matter how long a lazy man lives, he constitutes nuisance to humanity. To an Ijesa man, as enshrined in proverb 8 below, a lazy man deserves to die because his existence is a loss to humanity:

\section{B'ébi bá n p'òle e jé kókú, ìgbà tí kò kú kí lowó òle ràn?}

(Leave a lazy-man to die of hunger for his existence means nothing)

To an İjèsàman, a dead man is better than a lazy man, hence they prefer to do odd jobs instead of demeaning themselves by living a life characterized with stealing, borrowing or dehumanising beggarliness. Instead of engaging in such demeaning acts for survival, an İjèsàman prefers to do odd jobs such as labourers, messengers, cleaners, gardeners just to mention but few in order to prevent their integrity, privacy and independence from being trampled upon with impunity. This is the reasoning in the proverb below:

Kí á bá se bí elédè l'Oyìgbò, á máa lé se bí Adégborò l'ójà Oba

(If we hate dirt at Oyìgbò, we cannot be like a prince in the market) 
This is an epic proverb. Adégborò was an industrious Ìjèsà prince. In spite of his royal birth, he travelled to Òyìgbò market located in far Lagos where nobody knew his identity. He worked assiduously there and acquired substantial wealth. When his father's throne became vacant, the kingmakers sent for him to contest alongside with other princes. Owing to his intellectual and material wealth, Adégborò was selected by Ifa oracle to succeed his father and his reign was successful because he brought his resourcefulness to bear. Many İjèsà indigenes were empowered and consequently, the proverb became enacted in appreciation of his hardwork and resourcefulness. Literally, the proverb means if one does not behave like pig at Oyingbo, one cannot pose like Adégborò in Oba's market. Pig is a domestic animal hated for its dirtiness, Prince Adégborò did not mind his princely birth, he worked like pig but acquired not only material wealth but also intellectual wealth with which he liberated his subjects economically. Connotatively therefore, the proverb means that the İjèsàs do not rely on their parents' success, but they prefer to walk through the hard way to their success.

\section{Àgbè kó dáko kíé gbe kòkó, omo rè á sépè le}

(If a farmer plants not cocoa in his farm, he is cursed by his children)

Still on hard work and integrity, the İjèsàs believe that parents should work hard and show their children the way to be independent in life. Since their major occupation is farming, cocoa is the main cash crop which forms their source of revenue. While many of them are cocoa farmers, some are cocoa merchants. Every man therefore tries to work hard in order to leave an enduring legacy (cocoa plantation) behind. No matter how successful a farmer might be, if he left no cocoa plantation for his children to inherit, his spirit will not rest in peace because the customary rites which usually characterize the burial of successful men will not be accorded to such farmer after his death. To this end, the proverb literally means that the children of a farmer who refuses to plant cocoa will curse him. An average İjèsà man believes that the only antidote to hereditary poverty is hard work with integrity exemplified in the property left behind.

\section{Courage and Bravery}

\section{Ulésà ogbòn İjèbú ogún, ogún le rá m'ógbòn lára}

(Ilesa parades 30 ijebu parades 20, 20 cannot be completely wiped out by 30 )

Courage and bravery are other qualities of the Ijesas. They are fearless fighters for freedom, justice and equity. They are always ready to defend their right even with the last drop of their blood. History has it that upon the consistence of Ogedengbe and Fabunmi Oke-Mesi (the foremost Ijesa and Ekiti warlords respectively), Latoosa and his Ibadan warriors were humbled during the Ekitiparapo war between 1877 and 1893. The victory earned them the nick-name "alágídí" (stubborn or heady persons). At a point in the history of Ìjèsà land, IjebuJesa, one of the major towns that constitute İjèsà land attempted a secessionist mission due to marginalisation and quest for self-determination, they dared Owá Obòkun of Ìjèsà land. They were however suppressed but proverb 11 coined at the beginning of the insurrection, which mathematically means "Ilesa was 30 and Ijebu-Jesa 20, 20 could not be completely wiped out by 30 , still remains till today. This shows how courageous and fearless they were.

\section{Faithfulness}

\section{Ògún ulé ni an kókó ó bé, kan í sè bé t'òde}

(Home god is first appeased before that of the public)

The Ìjèsàs are very faithful and religious, before Christianity and Islam were imported, they held tenaciously to their traditional believes in Ògún-the god of iron, Sàngó-the god of thunder, 
Ifá-the god of divinity and wisdom, Èsù, Sònpòná or Olúayé, just to mention but few as exemplified in proverb 12 above. The proverb originated from the annual "Iwude" festival before which "Owá," who always presides over the worshipping session at "Eréjà" Square where ògún shrine is situated, must have offered dog to Ògún at his own personal shrine before coming out to duplicate the same rite at the public shrine. It is mandatory for each family head to perform similar rite at home to offer prayers for his family members far and near before joining Owá at Eréjà. The significance of this is that the home god is more revered and it deserves greater attention than the public one. Functionally, the proverb used to warn somebody who refuses to put his house in order, but is busy posing like a public figure or demagogue.

\section{Ifá ó polóó rè á dékun eran jíje, àjé ó bá poko rè á nùkàn sùn}

(Ifá oracle that kills its priest ceases eating meat, a witch kills her husband sleeps alone)

If a that kills its priest ceases to eat meat, the witch that kills her husband will sleep alone. Proverb 13 is the revelation of the fervent belief of the İjèsàs in Ifá divination. It underscores the essence of man even in the affairs of gods. Literally, Ifa is worshipped by a priest whom the İjèsàs refer to as "babaláo"or "olóó ifá" (idol's owner). No matter the excessiveness of the man to the oracle, he must not be killed by the spell of the oracle. This is because the day the man dies, all the clients that used to come and consult the oracle for solution to their problems through the priest will surely stop coming and by extension, the sacrifices that usually accompany the consultation will also cease and by implication, when sacrifices are no longer offered to an oracle, it dies a natural death. In the same vein, the İjèsàs believe that women join witchcraft for various reasons ranging from self-defence to protection of their children and household. Witches are spiritually powerful that they can kill anybody who attempts to tamper with their loved ones. However, when a witch decides to kill her husband, whom she is supposed to protect, she is believed to have gone beyond her bounds and the penalties were usually banishment and deprivation from meeting with men. The ethno-linguistic implication of the proverb is that extremism in everything is bad.

\section{İgbàgbó òkè-Oòyè ló mú ni i p’àbúò oni l'álàgbà}

(Òkè-Oòyè's faith demands calling one's younger brother an Elder)

The Apostolic Church where Prophet Ayo Babalola performed the healing miracle in 1930 is located at Òkè-Oòyè in Ilesa. Some leading Ijesa Christians like late Prophet Timothy Obadare, Pastor Enoch Adeboye, Pastor Abiara, and late Apostle J. O. Fakeye who were leading anointed of God all over the world hail from Ilesa and were inspired by the historic prophetic healing. The ministries of these God's Apostles have tremendous influence on many Ijèsà sons and daughters. In the doctrine of the Apostolic Church, positions are occupied not in terms of age but in terms of service and devotion to the work of God. The branch of the church at Òkè-Oòyè is the national headquarters where the doctrine is extremely enforced. Among the offices to which members are ordained are Deacon (Díákónì), Elder (Alàgbà), Pastor (Àlùfáà) and Apostle (Olùsó-àgùtàn). Meanwhile in İjèsà dialect, "alàgbà" means "elder." To an İjèsà man therefore, it looks incongruous for an elderly brother to be calling his younger brother an Elder if the latter is ordained in the church. The proverb preaches moderation in everything even in faith; it is used by the Ijjèsàs to rebuke and warn their children or relatives who choose to extremism in life.

Kí an wójò láyé gbogbo kí án rí, àn a bèrìsà Èsà-òkè lowè

(If drought persists throughout the world, we appease Èsà-Òkè god) 
Proverb 15 reveals the people's fervent belief and faith in God through whom all impossibilities become possible. Èsà-Òkè is one of the big and ancient towns in İjèsà land where there exist men of wisdom. These wise men are often consulted throughout İjèsà land and beyond whenever there are irresolvable crisis be it natural, spiritual, domestic or artificial; their interventions have always led to urgent solutions to the problems. One of these wise men is particularly renowned as the god of rain because the entire kingdom used to rely on him for early rain to enhance their agricultural works. When he is consulted for rain, he always makes use of an egg of local hen and other ingredients. As soon as he sets the charm on fire, he always asked his clients to return home because if they waist time, heavy rain will prevent them from returning home that day. Although Christianity and Islam have tremendously affected the people's belief in the traditional gods, the proverbial speech-act still exists up till today to restore hope, light and peace where there are hopelessness, darkness and conflicts respectively.

\section{Rational and logical thinkers}

Ugbi egbe oni ba mi sare ola, ure ola lo ye koni a sa

(When others hustle for wealth, one hustles for tomorrow)

Rational and logical thinking is synonymous with agídí-İjèsà. This is encapsulated in their proverbial lore above. In İjèsà dialect, "olá" (wealth) and "olà" are homophones. Customarily therefore, children and adults of the same age grades often nurse different ambitions. Some prefer to get rich quickly while few ones prefer to ponder about their future. Experience revealed that even if the first group succeed, their wealth does not always last long compared with the second group that pursue their ambition patiently. They are often bestowed with long lasting wealth, immaculate history and indelible foot prints on the sands of time. The İjèsàs use the proverb to educate their children to seize the opportunity of today to prepare themselves for tomorrow. Opportunities of today may be one's inheritance from parents or relatives, good job or a sudden fortune. To an Ìjèsà man, a rational thinker must not squander them but he must invest them to cater for his future.

\section{Oloja o je ko fiyun bole usi ni, yee o tu je ko u usi naa ni ere}

(The monarch who plants silver makes history, so also the one who uproots it)

This İjèsà proverb is in the realm of logical and rational reasoning, it pinpoints one's contribution to humanity. Owá is the traditional head of İjèsà kingdom, for administrative conveniences, each of the villages is headed by "Olójà" or "Lójà" who is directly responsible to Owá. In order to maintain peace and keep his domain progressing, a Lójà or village head tries to satisfy his subjects as well as the Owá. Failure to do this always attract sanctions such as removal or violent demonstration and when this happens, no member of the family of such village head will be allowed to rule the village forever. Reference is often made to remind the people that such family has opened bad record for themselves in history. In the contrary, a village head who distinguishes himself while in office is always remembered for good.

\section{Respect for elders and constituted authorities Ojú mérin léé bímo, ugba ojú léé wòó}

(If four eyes give birth to a child, two hundred eyes will train him)

One of the fundamental ethos in Ijesa proverbs is the respect for elders and constituted authorities. Miscreants and touts or uncultured children who have little or no respect for elders and constituted authorities are referred to as "Omo-alejà," they have no place in the scheme of things in İjèsà land. Proverb 16 is a proverbial synecdoche, two eyes stand for each 
of the two parents and two hundred eyes stand for the uncountable number of people that are responsible for the moral upbringing of the child. The belief is that God gives the child to the parents in trust; the child is actually the property of the society.

\section{K'ómodé bá r'ajá kó bá só ní kí t'àgbà mose, ikòrikò léé gbájá à ún}

(If a child trains his dog to ignore elders wish, the dog is devoured by a wolf)

In order to instil respect for elders in the mind of the younger ones, the İjèsàs make their children to learn even from the animals. Dog is one of the pets which children can keep, as the owner of the dog cannot justifiably disrespect an elder in the society without a proportionate sanction, so also his dog. Therefore, as the child tries to respect the elders and the constituted authorities, he has to instil the same discipline in his dog too. At the connotative level, the dog refers to the children and the entire household of a young man. If a young man refuses to put members of his household in order, they will incur the wrath of the law.

\section{Komode ba foju di esu, aa ba nao re tan}

(If a child defies the devil, he will be sent to unmitigated bankruptcy)

At times, fortune may smile at a child early in life; such a child should not despise an elder who is not as successful as he does. This is because a child cannot and can never be as experienced as an elder no matter his exposure. If a successful young man despises an elder on account of his wretchedness, the İjèsàs refer to such young man as proud. Parents, friends and relatives of such young man will not leave any stone unturned to make him to adjust to the societal values. If the young man continues in the same behaviour, he is liable to whatever tragic event that happens to him. In many occasions, such young man always encounters insurmountable problems.

\section{Sense of humour}

\section{Kí àn bá í kóbìnrin laa mólórí burúkú ulé rè á, oko rè láa mú}

(If a woman is to bring out the wretched man in her life, she will pick her husband)

Ijesa proverbs are receptive to humour. That is why most comedians and other theatre practitioners threat their audience to a great deal of Ijesa proverbs. Proverb 19 above sounds humorous, it however expresses a philosophical realism about what Adegoju (2009: 59) calls "compulsive social proximity" which, according to him occurs when people of different background live in the same geographical space. Consequently, they offend one another. Humour in literary works is meant to teach moral lesson in a comic way Àjàyí (2010: 124).

\section{CONCLUSION}

In this article, we have revealed that the concept of "agídí-İjèsà" is not semantically pejorative. Rather, it is a conclusion reached to eulogise the courage, bravery, altruism, faithfulness, sensitivity, consistence, truthfulness, hospitality, industrious and enterprising acumen of the people. The assessment of the strength and the weakness of each ethnic group that constitutes this country, with a view to develop good leaders like Nelson Madiba Mandela, Julius Nyerere and Desmond Tutu, who considered leadership as a call to serve their people and humanity is a panacea to a realistic national integration. Twenty samples of Ijesa proverbs were analysed under eight headings signifying the impeccable qualities of the Ijesas viz: hospitality and generosity, enterprising and industrious, hardworking and integrity, courage and bravery, faithfulness, rational and logical thinking, respect for elders and constituted authorities and sense of humour. "Agídí-İjèsà" is not a pejorative concept; it is rather the embodiment of qualities needed for African rebirth and to fulfil our destiny as a people. 


\section{References}

Achebe, C. (1985): Things fall apart, New York, Anchor Books.

Adegoju, A. (2009): "Rhetoric in Conflict-Related Yoruba Proverbs: Guide to Constructive Conflict Resolution in Africa" In African Study Monographs. 30 (2), 55-69.

Akakuru, I. (2008): French and English Idioms and Proverbs, Port Harcourt, Pearl Publishers.

Akmajian, Adrian et al. (2009): Linguistics: An Introduction to Language and Communication, New Delhi, PHI Learning.

Emordi, I. A. \& Mebitaghan, O. R. (2010): “Traduire le Proverbe Africain: Les Proverbes dans «Anthills of the Savanah» de Chinua Achebe», In Revue Internationale de Littérature et de Linguistique Appliquée, Vol. 1 No. 01 , 112-103.

Folorunso, K. (2001): Pronoms et Reprises dans le Discours Ecrit en Français et en Yoruba, Unpublished Ph D Thesis, Université Lumière-Lyon II.

Greenberg, J. H. (2010): Encyclopaedia Britannica. Ultimate Reference Suite, Chicago.

Kourouma, A. (1998): En Ettendant le Vote des Bêtes Sauvages, Paris, Edition Seuil.

Oyeweso, 'Siyan (2011): Ijesa Icons and the Making of Modern Nigeria, O. \& A. LTD, Ibadan.

Schmitt, Norbert: An Introduction to Applied Linguistics, London, Hodder Education,2010.

Salaudeen, I. A.: "Pragmatisme des Proverbes et Métaphores africains dans le Français de Monnè, Outrages et Défis d'Ahmadou Kourouma » In Revue Internationale de Littérature et de Linguistique Appliquée, Vol 1, No. 01, 2010, 190-195.

Wende, Olaosebikan : Formation, Sens et Usages du Proverbe : Une Etude Sémantico-Syntaxique de En Attendant le Vote des Bêtes Sauvages d'Ahmadou Kourouma,Unpublished M. A. Project, University of Ibadan, 2003.

Dictionaries and sitography

Déconstruction. (2016): In Encyclopædia Britannica. Retrieved from http://www.britannica.com/topic/deconstruction

Grand Dictionnaire Anglais. (2007): Great Britain, Oxford \& Hachette.

Le Petit Larousse Illustré. (2007): Paris, Larousse. 